\title{
Gender Disparities in Urban and Regional Planning Education in Selected Universities in Southwestern Nigeria
}

\author{
Abolade, Olajoke *Adigun, Folasade Oyenike Ojo, Phillip Oluwaseun Odunola Olaitan Olutayo \\ Adejumobi, David Oyinlade \\ Department of Urban and Regional Planning, Ladoke Akintola University of Technology, \\ Ogbomoso, Nigeria \\ *Corresponding Author
}

\begin{abstract}
The paper assesses gender disparities in Urban and Regional Planning (URP) education in Ladoke Akintola University of Technology (LAUTECH) and Federal University of Technology, Akure (FUTA). Simple random sampling method was employed to administer 225 questionnaires in both institutions. Secondary data on student's enrolment between 2003 and 2013 was obtained from the departments of Urban and Regional Planning of both institutions. 'Factors of Gender Disparity Index' (FGDI) was developed to measure factors responsible for gender disparities in planning education in the two institutions. Findings revealed that the ratio of male to female in all the academic sessions investigated varies in the selected institutions. In FUTA it was observed that the highest ratio of male: female is 4:1 while the lowest ratio is 5:2. However, in LAUTECH, the highest 'gender disparity range' is 7: 4 while the lowest is 3:2. The factor with the highest FGDI in LAUTECH is 'course is preferably taken by male' (3.19) while in FUTA, 'male can handle pressure situations better than female' (3.1). Other factors of significant FGDI are: 'very low interest in the course on the part of female students', and 'the stress undergone during the process of the course'. The study recommends increasing awareness on the prospects and professional benefits of Urban and Regional Planning (TOPREC) education through the Town Planners' Registration Council. Policies on tertiary education programme should deal with gender-stereotyped and bias courses.
\end{abstract}

Keywords: gender, disparity, URP,

DOI: $10.7176 / \mathrm{DCS} / 9-9-04$

Publication date:September $30^{\text {th }} 2019$

\subsection{INTRODUCTION}

Natural and human resources are common endowment of all nations of the world but the distribution varies. There is no nation that is not bequeathed with resources but it is not equal. For instance the population of India was estimated at 1,128,000 while Brazil was 186,250,000. However, developing countries like Liberia was estimated as 328,300 compared to Nigeria population estimated as 140, 431,790 in 2006 (NPC, 2006). This disparity is not limited to population size; it is also reflected in gender distribution. This inequality attracted the attention of international communities and thus several campaigns at conferences and workshops have been held for more equitable distribution of the world resources between men and women (Onsongo, 2006).

According to Hayley (2013), the estimated population of women in United States is more than half (50.8\%) compared to men $(49.2 \%)$. This contradicts the population of women in Nigeria where a larger $(71,345,488)$ proportion of male inhabitants was recorded as against the number $(69,086,302)$ recorded for female (NPC, 2010). Against this shortfall, and coupled with the fact that the disparity is not limited to population but there are other several implications especially on distribution of social amenities as well as access to education. Access to education has been a major challenge particularly in developing and under developed nations. This was reported by UNESCO (2012) that girls and women remained deprived of full and equal opportunities for education. This was further established by Alade (2013) that women still suffer discrimination in all ramifications including access to education. In Nigeria, the Federal Government of Nigeria (1998) emphasizes equal educational opportunities to citizens irrespective of their gender, religion, social class and ethnic affiliation. This became necessary so as to comply with the requirements for gender equity.

Until now, there have been several misconceptions on conceptual meaning of gender particularly when it is confused with "women" or sex. The term "gender" refers to a socially constructed characterization of women and men. According to UN-Habitat (2003), gender is described as social and cultural attributes as well as opportunities associated with being a male or female. Gender is further described as range of physical, biological, mental and behavioural characteristics pertaining to, and differentiating between, masculinity and feminity (Wikipedia, 2010). Gender analysis entails having knowledge of both women and men's roles and responsibilities. It is also the comparative analysis between these two that will reveal the gender inequalities of any society. This is the major preoccupation of this paper.

Gender inequality is one of the contemporary issues which have featured prominently in both national and international debates (Alade, 2013). Consequently, much has been achieved in the area of discourse on gender equality or inequality, gender balance, gender violence, gender mainstreaming gender imbalance among others (Alade, 2013; Haylee, 2013; OECD, 2011; Barrington, 2003). However, gender imbalance is evident in almost 
every aspect of human endeavour and particularly in education sector. This is revealed in the report of UNESCO, (2006) that the literacy rate of the worlds" women $(71.2 \%)$ is significantly lower than that of men $(83.6 \%)$. The report also showed a disproportionate distribution in level of literacy, where two thirds of the world illiterates' adults are women (565million) most especially from countries like Asia, Latin America and Africa.

The neglect of gender equality in science and technology education undoubtedly resulted to partial use of the resources available. According to Akilaiya and Ogbene (2000); and Josiah and Archy, (2001), gender disparity have been observed to exists in the Nigerian Educational sector in the last two decades. The need for gender balance in tertiary institutions needs to be emphasized, in view of the unique roles played by each group in every sphere of human endeavour. Consequently, the concept of gender in a society determines the way of life of members in that society. Coupled with this fact, most women in this dispensation have aspiration for higher heights or better life. Thus, improving girl access to professional courses like Urban and Regional Planning in higher institution with the goal of attaining gender equality, is a critical component of promoting development and meeting the Millennium development goals (MDGs7) in Nigeria. The paper therefore examines gender disparities in admission into Urban and Regional Planning education in Federal University of Technology Akure (FUTA) and Ladoke Akintola University of Technology (LAUTECH). The selection of both Universities is justified based on the fact that the former is governed by Federal Government while LAUTECH is an autonomous public institution owned by two states. However, both Universities have similarity in the edict that establishes them as University of Technology. The two Universities are specialized in producing graduates that are adequately equipped in practical as well as theoretical knowledge. Furthermore, the condition of learning and system of admission may differ, because most State Universities accommodate more students so as to increase internally generated revenue (IGR) for the institution as against fewer number that are mostly admitted in Federal Universities.

\subsection{RESEARCH METHODOLOGY}

Information was obtained from two sources: primary and secondary sources. The primary information was collected through the use of structured questionnaire. The list of student's enrolment for the past ten (10) years i.e $2003 / 2004$ to $2012 / 2013$ was procured from the selected Universities. This provides data on gender distribution of students' enrolment for the last ten (10) years so as to establish variation in the same.

Students were chosen at random to express their views on gender disparity and their perception of choice of the course of study. One hundred and twenty copies of the structure questionnaire distributed to twenty- five percent of male and female students in each of the five (5) levels (classes) to students of Urban and Regional Planning in Federal University of Technology Akure. In Ladoke Akintola University of Technology, 12.5\% of males and females in each of the class/levels were sampled. Different proportions were used in the two universities based on their varying population size. The population of students studying Urban and Regional Planning in Federal University of Technology Akure is five hundred (500) students while that of Ladoke Akintola University of Technology is nine hundred and ninety four (994), almost double the total size of Federal University of Technology Akure ( Tables 1 and 2).

Table 1: Population of Students and Sample Size in FUTA.

\begin{tabular}{|l|l|l|l|l|l|l|l|}
\hline S/N & $\begin{array}{l}\text { CLASS } \\
\text { LEVEL }\end{array}$ & MALE & FEMALE & $\begin{array}{l}\text { CLASS } \\
\text { POPULATION LIST }\end{array}$ & $\begin{array}{l}\text { MALE } \\
\text { SAMPLE }\end{array}$ & $\begin{array}{l}\text { FEMALE } \\
\text { SAMPLE }\end{array}$ & $\begin{array}{l}\text { TOTAL } \\
\text { SAMPLE }\end{array}$ \\
\hline 1 & 100 & 71 & 31 & 102 & 18 & 8 & 26 \\
\hline 2 & 200 & 69 & 29 & 98 & 17 & 7 & 24 \\
\hline 3 & 300 & 74 & 36 & 110 & 18 & 9 & 27 \\
\hline 4 & 400 & 66 & 28 & 94 & 16 & 7 & 22 \\
\hline 5 & 500 & 69 & 27 & 96 & 17 & 7 & 22 \\
\hline TOTAL & 349 & 151 & 500 & 86 & 38 & 119 \\
\hline
\end{tabular}

Source: Department of Urban and Regional Planning, FUTA, (2014) 
Table 2: Population of Students and Sample Size in LAUTECH, Ogbomoso.

\begin{tabular}{|l|l|l|l|l|l|l|l|}
\hline S/N & $\begin{array}{l}\text { CLASS } \\
\text { LEVEL }\end{array}$ & MALE & FEMALE & $\begin{array}{l}\text { CLASS } \\
\text { POPULATION LIST }\end{array}$ & $\begin{array}{l}\text { MALE } \\
\text { SAMPLE }\end{array}$ & $\begin{array}{l}\text { FEMALE } \\
\text { SAMPLE }\end{array}$ & $\begin{array}{l}\text { TOTAL } \\
\text { SAMPLE }\end{array}$ \\
\hline 1 & 100 & 93 & 68 & 161 & 12 & 8 & 20 \\
\hline 2 & 200 & 162 & 84 & 228 & 20 & 10 & 30 \\
\hline 3 & 300 & 143 & 77 & 220 & 18 & 10 & 28 \\
\hline 4 & 400 & 91 & 113 & 204 & 4 & 2 & 6 \\
\hline 5 & 500 & 87 & 94 & 181 & 11 & 12 & 23 \\
\hline
\end{tabular}

Source: Department of Urban and Regional Planning, LAUTECH, Ogbomoso, (2014)

The data analysis was both descriptive and inferential. The sex and age characteristics of students were summarized into frequencies and presented in Tables. An index termed 'Factors of Gender Disparity Index' (FGDI) was developed to measure the level of students' agreement on factors responsible for gender disparities in planning education in the two institutions. This was measured on Likert scale of four as 'strongly agreed', 'agreed', 'disagreed', and 'disagreed'. The FGDI were obtained by dividing the summation of weighted value (SWV) by the total number of responses. The SWV of each variable is the addition of the product of the proportion of responses to it and the weighted value attached to each rating. The values attached to different degree of responses is as shown below:

Strongly Agreed (SA) $=4$

Agreed (A) $=3$

Disagree (D) $=2$

StronglyDisagree(SD) $=1$

\subsection{FINDINGS AND DISCUSSIONS}

\section{Gender Disparity Gap in Enrolment of Student in FUTA and LAUTECH}

The gender distribution of students admitted for the past ten (10) years in the Department of Urban and Regional Planning, Federal University of Technology, Akure is summarized in Table 3. It was observed that in all the sessions the distribution of male students is between $67-85 \%$ while the proportion of the female students is 15 $33 \%$. The ratio of male to female in all the sessions investigated varies. The ratio with the smallest gap within the year of study is 5:2 in year 2007/2008. In this situation, out of seven students admitted, five were male while only two were female students.

Table 3: Enrollment Data into URP department in FUTA (2003/2004 - 2012/2013) Session

\begin{tabular}{|l|l|l|l|l|l|l|l|}
\hline S/N & SESSION & MALE & FEMALE & TOTAL & MALE\% & FEMALE\% & RATIO \\
\hline $\mathbf{1}$ & $\mathbf{2 0 0 3 / 2 0 0 4}$ & 38 & 07 & 45 & 84.4 & 15.6 & $4: 1$ \\
\hline $\mathbf{2}$ & $\mathbf{2 0 0 4 / 2 0 0 5}$ & 44 & 08 & 52 & 84.6 & 15.4 & $4: 1$ \\
\hline $\mathbf{3}$ & $\mathbf{2 0 0 5 / 2 0 0 6}$ & 48 & 12 & 60 & 80 & 20 & $4: 1$ \\
\hline $\mathbf{4}$ & $\mathbf{2 0 0 6 / 2 0 0 7}$ & 53 & 11 & 64 & 82.8 & 17.2 & $5: 1$ \\
\hline $\mathbf{5}$ & $\mathbf{2 0 0 7 / 2 0 0 8}$ & 53 & 15 & 68 & 77.9 & 22.1 & $5: 2$ \\
\hline $\mathbf{6}$ & $\mathbf{2 0 0 8 / 2 0 0 9}$ & 69 & 27 & 96 & 71.8 & 28.2 & $7: 3$ \\
\hline $\mathbf{7}$ & $\mathbf{2 0 0 9 / 2 0 1 0}$ & 66 & 28 & 94 & 70.2 & 29.8 & $7: 3$ \\
\hline $\mathbf{8}$ & $\mathbf{2 0 1 0 / 2 0 1 1}$ & 74 & 36 & 110 & 67.3 & 32.7 & $7: 4$ \\
\hline $\mathbf{9}$ & $\mathbf{2 0 1 1 / 2 0 1 2}$ & 69 & 29 & 98 & 70.4 & 29.6 & $7: 3$ \\
\hline $\mathbf{1 0}$ & $\mathbf{2 0 1 2 / 2 0 1 3}$ & 71 & 31 & 102 & 69.6 & 30.4 & $7: 3$ \\
\hline
\end{tabular}

Source: Department of Urban and Regional Planning, FUTA, (2014).

The ratio with the widest gap (4:1) is recorded in year 2010/2011. This indicates that out of every five students admitted only one was a female student compared to four males. The range in ratio of male: female is between 5:2 and $4: 1$. It is observed from the data that the gap between male: female admission seems to be closing up but not yet desirable. The implication of this on national development is enormous. 


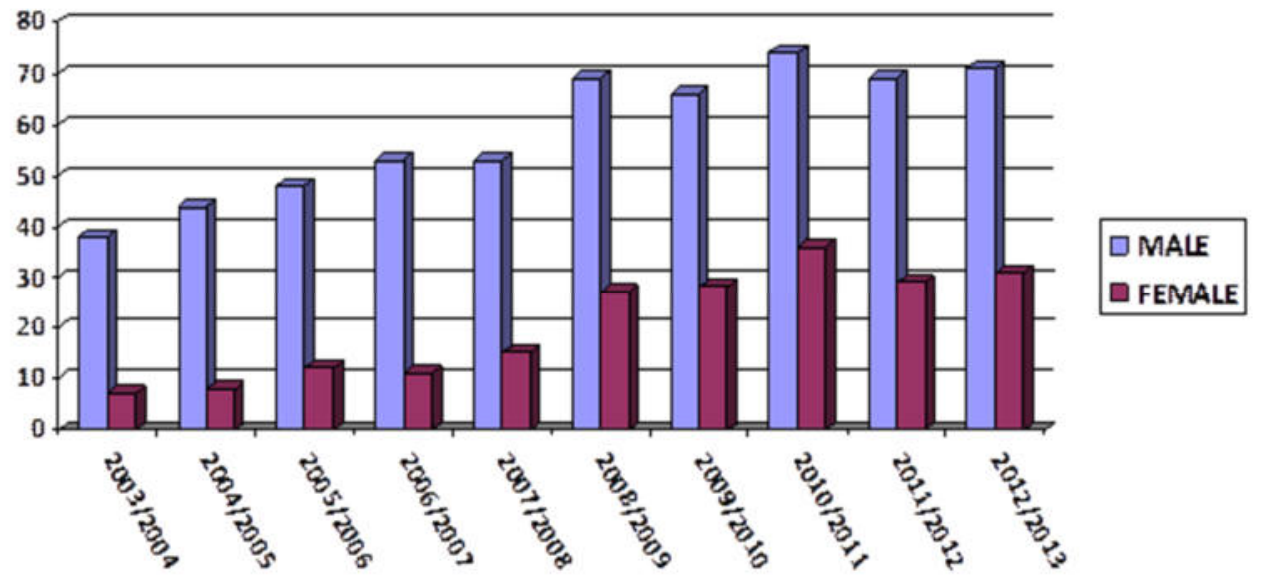

Fig 1: Male: Female Population of Students admitted for URP in FUTA, Akure Source: Department of Urban and Regional Planning, FUTA, (2014).

The gender distribution of students admitted for the past ten (10) years in the Department of Urban and Regional Planning in Ladoke Akintola University of Technology is documented in Table 4. The distribution fluctuates. In all the sessions, there are more male students than female except in 2008/2009 session when the female population (55.4\%) overshot that of male (44.6\%). The smallest ratio is 3:2 in 2009/2010. This implies that in 2009/2010 the total number of male students (154) admitted compared to female (103) is in ratio 3:2. This is the only year when the when the gap is small. Other years it is as much as ratio 7:4. For instance in 2010/2011 male admission reached 143 while the female counterpart was just 77 . It is glaring that number of male students admitted doubled that of female. The 'gender disparity range' is $3: 2-7: 4$.

Table 4: Enrollment Data into URP department in FUTA (2003/2004 - 2012/2013) Session

\begin{tabular}{|l|l|l|l|l|l|l|l|}
\hline S/N & SESSION & MALE & FEMALE & TOTAL & MALE\% & FEMALE\% & RATIO \\
\hline $\mathbf{1}$ & $\mathbf{2 0 0 3 / 2 0 0 4}$ & 40 & 30 & 70 & 57.2 & 42.8 & $4: 3$ \\
\hline $\mathbf{2}$ & $\mathbf{2 0 0 4 / 2 0 0 5}$ & 60 & 34 & 94 & 63.8 & 36.2 & $2: 1$ \\
\hline $\mathbf{3}$ & $\mathbf{2 0 0 5 / 2 0 0 6}$ & 84 & 31 & 115 & 73 & 27 & $8: 3$ \\
\hline $\mathbf{4}$ & $\mathbf{2 0 0 6 / 2 0 0 7}$ & 88 & 46 & 134 & 65.7 & 34.3 & $9: 5$ \\
\hline $\mathbf{5}$ & $\mathbf{2 0 0 7 / 2 0 0 8}$ & 91 & 50 & 141 & 64.5 & 35.5 & $9: 5$ \\
\hline $\mathbf{6}$ & $\mathbf{2 0 0 8 / 2 0 0 9}$ & 91 & 113 & 204 & 44.6 & 55.4 & $9: 11$ \\
\hline $\mathbf{7}$ & $\mathbf{2 0 0 9 / 2 0 1 0}$ & 154 & 103 & 257 & 60 & 40 & $3: 2$ \\
\hline $\mathbf{8}$ & $\mathbf{2 0 1 0 / 2 0 1 1}$ & 143 & 77 & 220 & 65 & 35 & $7: 4$ \\
\hline $\mathbf{9}$ & $\mathbf{2 0 1 1 / 2 0 1 2}$ & 162 & 84 & 228 & 71 & 29 & $2: 1$ \\
\hline $\mathbf{1 0}$ & $\mathbf{2 0 1 2 / 2 0 1 3}$ & 93 & 68 & 161 & 57.7 & 42.3 & $9: 7$ \\
\hline & TOTAL & $\mathbf{1 0 0 6}$ & $\mathbf{6 3 6}$ & $\mathbf{1 6 2 4}$ & & & $\mathbf{5 : 3}$ \\
\hline
\end{tabular}

Source: Department of Urban and Regional Planning, LAUTECH, Ogbomoso.

The nature of urban and regional planning as a profession is not to labour/energy exertive or intensive yet there is no reason for the wide gap in admission. Two reasons can be adduced for this. The first reason could be institutional, where quota is given on admission based on gender. This could not be ascertained in this study. The second could be from the applicant. This occurred when there is low application for the course compared to application from male candidates. This may be premised on various factors such as low awareness of what the course entails, societal view of the course, the professional image portrayed by those practicing the profession, the gender of those currently practicing the profession and the manner by which the profession is practiced. To an average Nigerian, a town planning officer is synonymous to a' red marker' of building or an 'undertaker' of demolition. Such work may not be attractive to a female candidate seeking admission. This shows a high level of ignorance or awareness of what the profession entails. 


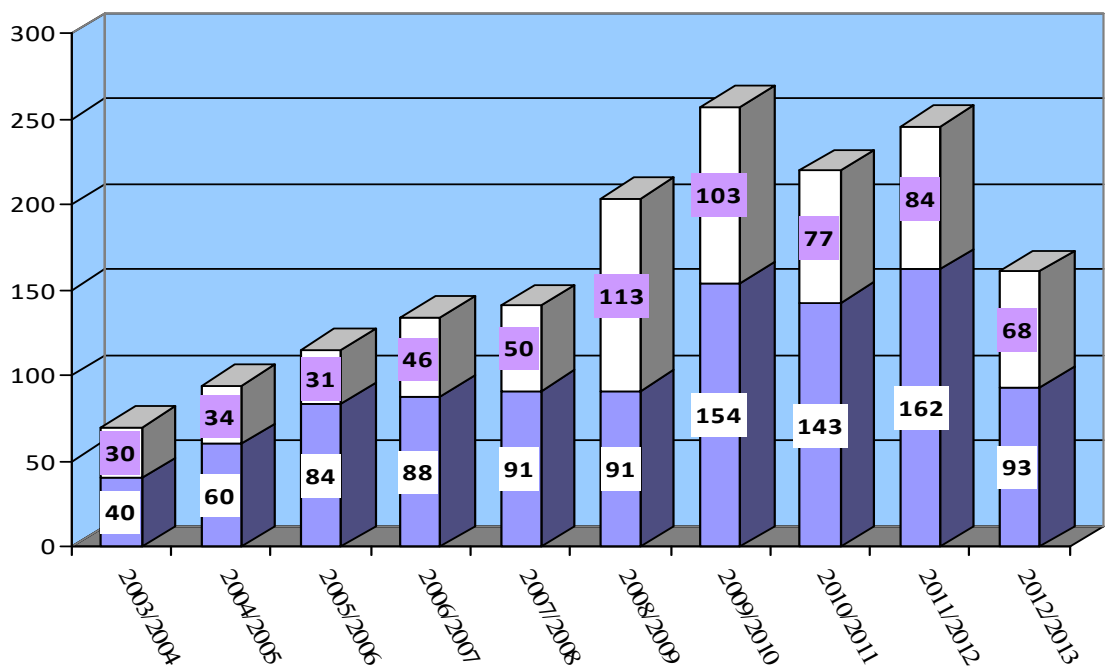

Fig 2: Male: Female Population of Students admitted for URP in LAUTECH, Ogbomoso. Source: Department of Urban and Regional Planning, LAUTECH, Ogbomoso.

Students' Perception of Factors Responsible for Gender Inequality in Students Admission

Likert scale was employed to determine the level of agreement placed on each of the variables employed for determination of factors responsible for gender inequality in the Urban and Regional Planning Education. In LAUTECH, the highest FGDI is 3.19 while the lowest is 1.94 (Table 3). The mean FGDI is 2.42. It is observed that the factor that indicates that male had personal preference for URP had the highest score (3.19). This implies that, (as perceived by the students), the course Urban and Regional Planning is preferably taken by the male sex. This is followed by variable 'Urban and Regional Planning is male sensitive than female' (3.12). Variables with FGDI above the mean indicate facts that respondents' strongly agree with. Variables with low FGDI are facts that respondents strongly disagree with. These include the 'course being taken by the female sex'.

Table 5: Factors Responsible for Gender Gap in Students Enrollment into Department of URP, LAUTECH, Ogbomoso

\begin{tabular}{|c|c|c|c|c|c|c|c|c|c|c|c|}
\hline \multirow[t]{3}{*}{$\mathbf{S} / \mathbf{N}$} & \multirow{3}{*}{$\begin{array}{l}\text { FACTORS RESPONSIBLE } \\
\text { FORGENDERINEQUALITY }\end{array}$} & \multicolumn{4}{|c|}{ RANKING } & \multirow[b]{2}{*}{$\mathbf{F}$} & \multirow[b]{2}{*}{ SWV } & \multirow{2}{*}{$\begin{array}{l}\text { FGDI= } \\
\text { SWV/F }\end{array}$} & \multirow{2}{*}{$\overline{\mathbf{X}}$} & \multirow[b]{2}{*}{ D } & \multirow[b]{2}{*}{$D^{2}$} \\
\hline & & SA & A & D & SD & & & & & & \\
\hline & & 4 & 3 & 2 & 1 & & & & & & \\
\hline 1 & $\begin{array}{l}\text { Urban and Regional Planning course } \\
\text { is preferably taken by male }\end{array}$ & 112 & 258 & 10 & 0 & 119 & 380 & 3.19 & 2.42 & 0.77 & 0.592 \\
\hline 2 & $\begin{array}{l}\text { Urban and Regional Planning ismore } \\
\text { male sensitive than female }\end{array}$ & 112 & 237 & 22 & 1 & 119 & 372 & 3.12 & & 0.7 & 0.491 \\
\hline 3 & $\begin{array}{l}\text { Malesarenaturallybetteratmostfield } \\
\text { works }\end{array}$ & 152 & 183 & 26 & 7 & 119 & 368 & 3.09 & & 0.67 & 0.448 \\
\hline 4 & $\begin{array}{l}\text { Most females are not interested in } \\
\text { planning due to praticals involved }\end{array}$ & 132 & 135 & 82 & 0 & 119 & 349 & 2.93 & & 0.51 & 0.260 \\
\hline 5 & $\begin{array}{l}\text { Male students generally do better in } \\
\text { designs than female students }\end{array}$ & 52 & 234 & 40 & 8 & 119 & 334 & 2.81 & & 0.39 & 0.152 \\
\hline 6 & $\begin{array}{l}\text { Males generally possess more design } \\
\text { skills than females }\end{array}$ & 72 & 204 & 50 & 8 & 119 & 334 & 2.80 & & 0.38 & 0.144 \\
\hline 7 & $\begin{array}{l}\text { Male can handle pressure situations } \\
\text { better than females }\end{array}$ & 28 & 240 & 50 & 7 & 119 & 325 & 2.73 & & 0.31 & 0.096 \\
\hline 8 & $\begin{array}{l}\text { Males are more outspoken than } \\
\text { females }\end{array}$ & 44 & 198 & 80 & 2 & 119 & 324 & 2.72 & & 0.30 & 0.09 \\
\hline 9 & $\begin{array}{l}\text { Males are strong while females are } \\
\text { weak }\end{array}$ & 80 & 186 & 38 & 18 & 119 & 316 & 2.65 & & 0.23 & 0.052 \\
\hline 10 & $\begin{array}{l}\text { Females are more outspoken than } \\
\text { males }\end{array}$ & 68 & 117 & 126 & 0 & 119 & 311 & 2.61 & & 0.19 & 0.036 \\
\hline
\end{tabular}

Source: Author's Field Survey, 2014 
Table 5 Contd: Factors Responsible for Gender Gap in Students Enrollment into Department of URP, LAUTECH, Ogbomoso

\begin{tabular}{|c|c|c|c|c|c|c|c|c|c|c|c|}
\hline \multirow{3}{*}{$\mathbf{S} / \mathbf{N}$} & \multirow{3}{*}{$\begin{array}{l}\text { FACTORS } \\
\text { RESPONSIBLE FOR } \\
\text { GENDER INEQUALITY }\end{array}$} & \multicolumn{4}{|c|}{ RANKING } & \multirow[b]{2}{*}{$\mathbf{F}$} & \multirow[b]{2}{*}{ SWV } & \multirow{2}{*}{$\begin{array}{l}\text { FGDI= } \\
\text { SWV/F }\end{array}$} & \multirow[b]{2}{*}{$\overline{\mathbf{X}}$} & \multirow[b]{2}{*}{ D } & \multirow[b]{2}{*}{$D^{2}$} \\
\hline & & SA & A & $\mathrm{D}$ & SD & & & & & & \\
\hline & & 4 & 3 & 2 & 1 & & & & & & \\
\hline 11 & $\begin{array}{l}\text { Method of admission process } \\
\text { allow more male to Urban } \\
\text { and Regional Planning }\end{array}$ & 28 & 156 & 98 & 11 & 119 & 293 & 2.46 & \multirow[t]{11}{*}{2.42} & 0.04 & 0.016 \\
\hline 12 & $\begin{array}{l}\text { Females can handle pressure } \\
\text { situations better than males }\end{array}$ & 68 & 57 & 150 & 8 & 119 & 283 & 2.38 & & -0.04 & 0.016 \\
\hline 13 & $\begin{array}{l}\text { Most males are not interested } \\
\text { in planning due to praticals } \\
\text { involved }\end{array}$ & 0 & 150 & 108 & 15 & 119 & 273 & 2.29 & & -0.13 & 0.016 \\
\hline 14 & $\begin{array}{l}\text { Females are naturally better } \\
\text { at most field works }\end{array}$ & 28 & 36 & 198 & 1 & 119 & 263 & 2.21 & & -0.21 & 0.044 \\
\hline 15 & $\begin{array}{l}\text { Female students generally do } \\
\text { better in designs than male } \\
\text { students }\end{array}$ & 0 & 114 & 134 & 4 & 119 & 262 & 2.20 & & -0.22 & 0.048 \\
\hline 16 & $\begin{array}{l}\text { Females generally possess } \\
\text { more design skills than males }\end{array}$ & 0 & 67 & 166 & 7 & 119 & 260 & 2.18 & & -2.42 & 0.055 \\
\hline 17 & $\begin{array}{l}\text { Females are strong while } \\
\text { males are weak }\end{array}$ & 0 & 87 & 164 & 8 & 119 & 259 & 2.17 & & -0.25 & 0.062 \\
\hline 18 & $\begin{array}{l}\text { Urban and Regional Planning } \\
\text { is more female sensitive than } \\
\text { male }\end{array}$ & 0 & 32 & 206 & 8 & 119 & 246 & 2.06 & & -0.36 & 0.129 \\
\hline 19 & $\begin{array}{l}\text { Method of admission process } \\
\text { allow more female to Urban } \\
\text { and Regional Planning }\end{array}$ & 0 & 54 & 178 & 12 & 119 & 244 & 2.05 & & -0.37 & 0.136 \\
\hline \multirow[t]{2}{*}{20} & $\begin{array}{l}\text { Urban and Regional Planning } \\
\text { course is preferably taken by } \\
\text { female }\end{array}$ & 0 & 0 & 224 & 7 & 119 & 231 & 1.94 & & -0.48 & 0.230 \\
\hline & Total & & & & & & & 17.538 & & & \\
\hline
\end{tabular}

Source: Author's Field Survey, 2014

In FUTA the highest FGDI was 3.10 while the lowest was 1.93. The mean FGDI is 2.57. The highest FGDI (3.10) is recorded for 'male can handle pressure situations better than females'. This implies that, as perceived by the respondents, the male sex can handle pressure situations better than the female sex. This is followed by variable 'Urban and Regional Planning is more male sensitive than female' (3.07). Variables with low FGDI includes 'females are strong while males are weak'. 
Table 6: Factors Responsible for Gender Gap in Students Enrollment into Department of URP, FUTA,

\begin{tabular}{|c|c|c|c|c|c|c|c|c|c|c|c|}
\hline \multirow{3}{*}{$\mathbf{S} / \mathbf{N}$} & \multirow{3}{*}{$\begin{array}{l}\text { FACTORS } \\
\text { RESPONSIBLE FOR } \\
\text { GENDERINEQUALITY }\end{array}$} & \multicolumn{4}{|c|}{ RANKING } & \multirow{3}{*}{$\mathbf{F}$} & \multirow{3}{*}{ SWV } & \multirow{3}{*}{$\begin{array}{l}\text { FGDI= } \\
\text { SWV/F }\end{array}$} & \multirow[b]{2}{*}{$\overline{\mathbf{X}}$} & \multirow[b]{2}{*}{ D } & \multirow[b]{2}{*}{$D^{2}$} \\
\hline & & \multirow{2}{*}{\begin{tabular}{|l|} 
SA \\
4
\end{tabular}} & \multirow{2}{*}{$\begin{array}{l}\text { A } \\
3\end{array}$} & \multirow{2}{*}{$\begin{array}{l}\mathrm{D} \\
2\end{array}$} & \multirow{2}{*}{$\begin{array}{l}\text { SD } \\
1\end{array}$} & & & & & & \\
\hline & & & & & & & & & \multirow{4}{*}{2.57} & & \\
\hline 1 & $\begin{array}{l}\text { Male can handle pressure } \\
\text { situations better than females }\end{array}$ & 164 & 84 & 74 & 7 & 106 & 329 & 3.10 & & 0.53 & 0.280 \\
\hline 2 & $\begin{array}{l}\text { Urban and Regional Planning is } \\
\text { moremale sensitive than female }\end{array}$ & 188 & 60 & 78 & 0 & 106 & 326 & 3.07 & & 0.50 & 0.25 \\
\hline 3 & $\begin{array}{l}\text { Mostmalesarenotinterestedin } \\
\text { planning due to praticals } \\
\text { involved }\end{array}$ & 128 & 111 & 74 & 0 & 106 & 313 & 2.95 & & 0.38 & 0.144 \\
\hline 4 & $\begin{array}{l}\text { Urban and Regional Planning } \\
\text { course is preferably taken by } \\
\text { female }\end{array}$ & 188 & 0 & 118 & 0 & 106 & 306 & 2.88 & & 0.31 & 0.096 \\
\hline 5 & $\begin{array}{l}\text { Females are naturally better at } \\
\text { most field works }\end{array}$ & 76 & 159 & 68 & 0 & 106 & 303 & 2.86 & & 0.29 & 0.084 \\
\hline 6 & $\begin{array}{l}\text { Males generally possess more } \\
\text { design skills than females }\end{array}$ & 120 & 75 & 102 & 0 & 106 & 297 & 2.80 & & 0.23 & 0.052 \\
\hline 7 & $\begin{array}{l}\text { Urban and Regional Planning } \\
\text { course is preferably taken by } \\
\text { male }\end{array}$ & 52 & 165 & 76 & 0 & 106 & 293 & 2.76 & & 0.19 & 0.036 \\
\hline 8 & $\begin{array}{l}\text { Urban and Regional Planning is } \\
\text { more female sensitive than male }\end{array}$ & 76 & 111 & 100 & 0 & 106 & 287 & 2.70 & & 0.13 & 0.016 \\
\hline 9 & $\begin{array}{l}\text { Males are strong while females } \\
\text { areweak }\end{array}$ & 112 & 57 & 118 & 0 & 106 & 287 & 2.70 & & 0.13 & 0.016 \\
\hline 10 & $\begin{array}{l}\text { Females are more outspoken } \\
\text { thanmales }\end{array}$ & 76 & 111 & 78 & 11 & 106 & 276 & 2.60 & & 0.03 & 0.004 \\
\hline 11 & $\begin{array}{l}\text { Male students generally do } \\
\text { better in designs than female } \\
\text { students }\end{array}$ & 76 & 60 & 134 & 0 & 106 & 270 & 2.55 & & -0.02 & 0.004 \\
\hline 12 & $\begin{array}{l}\text { Method of admission process } \\
\text { allow more male to Urban and } \\
\text { Regional Planning }\end{array}$ & 76 & 60 & 134 & 0 & 106 & 270 & 2.54 & & -0.03 & 0.009 \\
\hline 13 & $\begin{array}{l}\text { Female students generally do } \\
\text { better in designs than male } \\
\text { students }\end{array}$ & 0 & 168 & 68 & 16 & 106 & 252 & 2.38 & & -0.19 & 0.036 \\
\hline 14 & $\begin{array}{l}\text { Males are naturally better at } \\
\text { most fieldworks }\end{array}$ & 76 & 0 & 174 & 0 & 106 & 250 & 2.36 & & -0.21 & 0.044 \\
\hline 15 & $\begin{array}{l}\text { Females generally possessmore } \\
\text { design skills than males }\end{array}$ & 0 & 111 & 138 & 0 & 106 & 249 & 2.35 & & -0.22 & 0.048 \\
\hline 16 & $\begin{array}{l}\text { Females can handle pressure } \\
\text { situations better than males }\end{array}$ & 0 & 117 & 108 & 13 & 106 & 238 & 2.25 & & -0.32 & 0.102 \\
\hline 17 & $\begin{array}{l}\text { Males are strong while females } \\
\text { are weak }\end{array}$ & 76 & 0 & 142 & 16 & 106 & 234 & 2.21 & & -0.36 & 0.129 \\
\hline 18 & $\begin{array}{l}\text { Most females are not interested } \\
\text { in planning due to praticals } \\
\text { involved }\end{array}$ & 0 & 147 & 58 & 28 & 106 & 233 & 2.19 & & -0.38 & 0.144 \\
\hline 19 & $\begin{array}{l}\text { Males are more outspoken than } \\
\text { females }\end{array}$ & 0 & 57 & 174 & 0 & 106 & 231 & 2.18 & & -0.39 & 0.152 \\
\hline 20 & $\begin{array}{l}\text { Females are strong while males } \\
\text { areweak }\end{array}$ & 0 & 27 & 162 & 16 & 106 & 205 & 1.93 & & -0.64 & 0.409 \\
\hline & Total & & & & & & & 51.36 & & & \\
\hline
\end{tabular}

Source: Author's Field Survey, 2014.

\subsection{IMPLICATIONS TO RESEARCH AND PRACTICE}

It is a common knowledge that education is the backbone of development in any nation, and it is also the propeller that drives the engine of national development. An accelerated approach to development should involve the active 
participation of both males and females. This research has been able to establish that gender disparity that exists in two institutions in southwestern Nigeria. The findings of this study show that in both institutions there is gender disparity gap i.e there are more male admitted than females. This is attributed to various factors such as low awareness of what the course entails, societal view of the course, the professional image portrayed by those practicing the profession, the gender of those currently practicing the profession and the manner by which the profession is practiced. There seems to be more to this gender gap than all these. Gender disparity arising from ignorance is dangerous than any other. A man cannot operate or function beyond the level of his/her understanding suffice to say that lack of knowledge will lead to neglect of opportunity and outright waste of resources. Then who is to be blamed. This has implication on the future of the profession as well as national development. The implication of this on human resource development is enormous.

The benefits of Urban and Regional Planning education can only accrue to any nation and her populace when various part of such nation is actively involved. It could however be addressed by creation of awareness starting from the child's first institution of learning i.e the home, then other formal or informal organizations such community and religious groups. Parents should create a home environment where a female girl is fashioned with the knowledge that she could choose any profession she desires in life irrespective of societal perspective. In addition a creation of public awareness of the prospects of URP as a profession should be embarked upon by Town Planners' Registration Council (TOPREC). This is to create public knowledge of the profession which could assist candidates seeking admission in taken the right decisions. It is further suggested that policies on tertiary education programmes should deal with gender-stereotyped and bias courses as well as securing fair school admission, direct access to course of choice among others. These will undoubtedly mainstream disparity and gender bias for professional courses like urban and regional planning in tertiary institutions. Furthermore, National Policy on Education should set up policy, innovations and changes to including repositioning science, technical and professional courses like URP. This will further promote National development and reduce gender gap or gender imbalance in the country.

\section{REFERENCES:}

Alade, I. A. (2012): Gender Stereotyping and Empowerment in Nigeria Society: Implications for Women Repositioning in Curriculum Delivery An International Journal of Language, Literature and Gender Studies Bairh Dar Ethopia Vol 1(1) pp30-43

Akilaiya, O and Ogbene A. E. (2000) "Women Education, Differential Fertility and Development in Nigeria "in African Journal of Research in Education Vol. 1, 3pp 50 - 58

Akujobi, C., \& Simmons, R. (2006). An Assessment of Elementary School service-Learning Teaching Methods Using Service-learning Goals. NSEE Quarterly, 23 (2), 19-28.

Barrington H. B. (2003): Gender Issues in Tertiary Education being a Speech Presented at the Association of Tertiary Education Annual Conference Held in Nassau, Bahamas at Breezes Hotel.

Department of Urban and Regional Planning (2014): Students Admission List for 2008-2013, Federal University of Technology, Akure.

Department of Urban and Regional Planning (2014): Students Admission List for 2008-2013, Ladoke Akintola University of Technology, Ogbomoso.

Federal Government of Nigeria (1998): The National Policy on Education. Lagos: NERDC Press

Haylee, M. (2013): The Planning Gender Gap www.mildredwarner.org

Josiah, M. A. And Archy, N (2001) "Enhancing Female Performance in Science Education in Nigeria: A case study of Federal College of Education, Pankglin In STAN 42nd Annual Conference proceedings pp $79-81$.

National Gender Policy, (2006): Federal Ministry of Women Affairs and Social Development.

National Population Commission (2010): Population Distribution by Sex, State LGA and Senatorial District :Population and Housing Census for 2006 Priority Table Vol 111

OECD (2011): Report on Gender Initiative Gender Equality in Education, Employment and Entrepreneurship Meeting of OECD council at ministerial Level Held at Paris 25-26 May 2011

Onsongo, J. (2006): Gender Inequality in Universities in Kenya. In C. Creighton and F. Yieke (Eds.), Gender Inequality in Kenya. UNESCO. Retrieved from http://unesdoc.unesco.org/images/0014/001458/145887e.pdf

UN-Habitat (2003) A Conceptual Guide to "Gender" http://www.unhabitat.org/gov

UNESCO (2012): World Atlas of Gender Equality in Education United Nations Educational, Scientific and Cultural Organization France

WIKIPEDIA (2010): http://en.wikipedia.org/wiki/Gender 